DOI: $10.29303 / \mathrm{jrpb} . v 9 \mathrm{i} 1.220$

ISSN 2301-8119, e-ISSN 2443-1354

Tersedia online di http://jrpb.unram.ac.id/

\title{
SIFAT MEKANIK BIOPLASTIK BERBASIS KOMBINASI PATI BIJI NANGKA DAN TONGKOL JAGUNG
}

\author{
Mechanical Properties of Bioplastic Based on The Combination of \\ Jackfruit Starch and Corn Cob
}

\section{Ida Ayu Widhiantari*), Agriananta Fahmi Hidayat, Surya Abdul Muttalib, Fakhrul Irfan Khalil, Isnaini Puspitasari} \author{
Universitas Mataram, Jl. Majapahit No. 62, Mataram 83125, Indonesia \\ Email ${ }^{*}$ : ida.ayuwidhiantari@unram.ac.id \\ Diterima: Desember 2020 \\ Disetujui: Maret 2021
}

Program Studi Teknik Pertanian, Fakultas Teknologi Pangan dan Agroindustri,

\begin{abstract}
Bioplastic is a type of plastic packaging that is environmentally friendly because it comes from organic materials so that it is easily broken down in the soil with the help of soil microorganisms. In this research, bioplastics were made from a combination of starch source materials, which are jackfruit seed starch and corncob starch. This study aims to analyze the effect of variations in the concentration of $3 \%, 6 \%$, and $9 \% \mathrm{ZnO}$ and $2 \mathrm{ml}, 5 \mathrm{ml}$, and $8 \mathrm{ml}$ glycerol on the mechanical properties of bioplastics. From the research results, it was found that the highest value of bioplastic tensile strength was obtained in the $\mathrm{ZnO}$ concentration treatment of $9 \%$, namely $2.5788 \mathrm{MPa}$. The concentration of glycerol is inversely proportional to the tensile strength value of bioplastics, where the highest tensile strength value was obtained at a $2 \mathrm{ml}$ glycerol concentration of $2.2775 \mathrm{MPa}$. The highest percentage of elongation value was obtained at the $3 \% \mathrm{ZnO}$ concentration of $13.237 \%$, while from the effect of glycerol concentration, the highest percentage of elongation value was obtained at the glycerol concentration of $8 \mathrm{ml}$, which was $13.8643 \%$.
\end{abstract}

Keywords: bioplastic; corn cobs; jackfruit seeds; starch

\begin{abstract}
ABSTRAK
Bioplastik merupakan jenis kemasan plastik yang ramah lingkungan karena berasal dari bahan organik sehingga mudah terurai di dalam tanah oleh bantuan mikroorganisme tanah. Dalam penelitian ini dilakukan pembuatan bioplastik dari kombinasi bahan sumber pati yaitu dari pati biji nangka ditambah dengan pati tongkol jagung. Penelitian ini bertujuan menganalisis pengaruh variasi konsentrasi $\mathrm{ZnO} 3 \%, 6 \%$, dan $9 \%$ dan gliserol $2 \mathrm{ml}, 5 \mathrm{ml}$, dan $8 \mathrm{ml}$ terhadap sifat mekanik bioplastik. Dari hasil penelitian didapatkan nilai tensile strength bioplastik terbesar diperoleh pada perlakuan konsentrasi ZnO sebesar 9\% yaitu sebesar 2,5788 $\mathrm{MPa}$. Konsentrasi gliserol berbanding terbalik dengan nilai tensile strength bioplastik, dimana nilai tensile strength tertinggi diperoleh pada konsentrasi gliserol $2 \mathrm{ml}$, yaitu sebesar 2,2775 $\mathrm{MPa}$. Nilai \% elongasi tertinggi diperoleh pada konsentrasi ZnO 3\%, yaitu sebesar 13,237\%,
\end{abstract}


sedangkan dari pengaruh konsentrasi gliserol, nilai \% elongasi tertinggi diperoleh pada konsentrasi gliserol $8 \mathrm{ml}$ yaitu sebesar 13,8643\%.

Kata kunci: bioplastik; biji nangka; pati; tongkol jagung

\section{PENDAHULUAN}

\section{Latar Belakang}

Penggunaan plastik dalam berbagai kebutuhan terus meningkat seiiring dengan bertambahnya jumlah penduduk. Penggunaan plastik sering ditemukan pada peralatan rumah tangga, barang-barang mainan anak, kantong belanjaan, sebagai media tanam (polybag) dan masih banyak yang lain. Setiap pembelanjaan baik di pasar tradisional maupun modern, selalu dipacking dengan menggunakan kantong plastik. Dengan demikian, tidak heran jika banyak sampah kantong plastik ditemukan di mana-mana.

Jenis plastik ini sangat sulit terurai (nonbiodegradable) oleh mikroorganisme di tanah walaupun telah lama berada di dalam tanah, sehingga keberadaaannya sangat mempengaruhi kelestarian lingkungan. Sering ditemukan plastik sisa makanan maupun plastik bekas packaging dibuang di sembarang tempat baik di sungai maupun di tanah ataupun sengaja dibakar untuk mengurangi volumenya. Pembakaran sampah plastik dapat membahayakan kesehatan manusia karena dalam proses pembakarannya dapat menimbulkan zat karsinogenik.

Melihat kondisi tersebut, sangat diperlukan adanya suatu perubahan yang dapat mengatasi masalah pencemaran lingkungan yang diakibatkan oleh keberadaan sampah plastik. Bioplastik menjadi solusi untuk dapat mengatasi keberadaan sampah plastik yang terus meningkat. Bioplastik merupakan jenis plastik yang ramah lingkungan karena berasal dari bahan organic, sehingga mudah terurai di dalam tanah oleh bantuan mikroorganisme tanah. Sumber bahan alam yang dapat digunakan dalam pembuatan bioplastik berasal dari bahan yang mengandung pati, selulosa, kitin, kolagen, dan juga lemak (Bourtoom, 2008). Seperti yang telah dilakukan oleh Aripin, et al., (2017), dimana menggunakan bahan dari pati ubi jalar dengan penambahan plasticizer gilserol dengan metode melt intercalation dan Asngad, et al., (2018), yang menggunakan kombinasi kulit kacang dengan pati bonggol pisang dan biji nangka dalam pembuatan plastik biodegradable.

Dalam penelitian ini dilakukan pembuatan bioplastik dari kombinasi bahan sumber pati, yaitu dari pati biji nangka ditambah dengan pati tongkol jagung. Kedua bahan ini merupakan limbah hasil pertanian yang tidak dimanfaatkan. Jika diolah, biji nangka dapat menghasilkan tepung. Begitu pula tongkol jagung, limbah ini dapat menghasilkan tepung yang dapat dimanfaatkan. Tepung yang dihasilkan dapat diekstraksi untuk menghasilkan pati, sehingga dengan menjadikannya sebagai bahan dasar dalam pembuatan bioplastik mampu meningkatkan nilai guna dari limbah tersebut.

\section{Tujuan}

Tujuan dari penelitian ini adalah menganalisis pengaruh variasi konsentrasi $\mathrm{ZnO}$ dan gliserol pada pembuatan bioplstik berbahan dasar kombinasi pati biji nangka dan tongkol jagung serta menjelaskan pengaruhnya terhadap sifat mekanik bioplastik dari kombinasi pati biji nangka dan tongkol jagung.

\section{METODE PENELITIAN}

\begin{abstract}
Alat dan Bahan
Peralatan yang digunakan terdiri dari timbangan digital, termometer, gelas ukur, ayakan 80 mesh, kain saring, toples, batu penggilas, kompor sebagai media untuk memanaskan bahan, cetakan dari plat kaca ukuran 13x13 cm, blender untuk menghaluskan bahan, dan tensile test
\end{abstract}


machine ASTM D638-14 Type IV. Sedangkan bahan yang digunakan antara lain biji nangka yang diperoleh dari Desa Suranadi, Kabupaten Lombok Barat, tongkol jagung yang diperoleh dari Desa Gerung Kabupaten Lombok Barat, air, aquades, $\mathrm{ZnO}$, gliserol, dan asam asetat.

\section{Prosedur Penelitian}

Proses pembuatan bioplastik yang dihasilkan pada penelitian ini terdiri dari beberapa tahapan antara lain yaitu dengan cara mengolah biji nangka dan tongkol jagung menjadi pati, pencampuran bahan dasar yakni dengan perbandingan pati biji nangka dan tongkol jagung $4: 1$, pembuatan larutan bioplastic, dan pencetakan. Penggunaan pati biji nangka lebih tinggi dibandingkan dengan penggunaan pati dari tongkol jagung, hal ini didasarkan pada kandungan pati pada biji nangka yang relatif tinggi dibandingkan dengan tongkol jagung. Pranamuda (2011) mengatakan bahwa pati biji nangka berkisar antara 40-50\%, sedangkan menurut Wardah \& Hastuti (2015), kandungan pati tongkol jagung sebesar $0,014 \%$. Namun, karena keberadaan tongkol jagung yang melimpah dan tidak dimanfaatkan sehingga tongkol jagung digunakan dalam pembuatan bioplastik dalam penelitian ini. Pengujian sifat mekanik bioplastik dilakukan dengan menggunakan alat uji tarik tensile test ASTM D638-14 Tipe IV.

Pembuatan pati biji nangka dilakukan dengan cara mengupas kulit biji nangka yang diperoleh. Kemudian biji Nangka dibersihkan dengan cara dicuci pada air yang mengalir, lalu diblender dengan pemberian tambahan air sampai menjadi bubur biji nangka. Setelah itu, bubur biji nangka diperas menggunakan kain. Hasil perasan kemudian didiamkan selama 24 jam untuk mendapatkan pati, kemudian dilanjutkan dengan pengeringan di bawah sinar matahari hingga kering. Setelah kering dilakukan penghalusan terhadap pati yang diperoleh dan diayak, sehingga diperoleh pati yang halus dan lembut. Begitu pula tahapan yang dilakukan pada tongkol jagung.

\section{Metode}

Rancangan pada penelitian ini dilakukan menggunakan Rancangan Acak Lengkap (RAL) dengan 2 faktor, yaitu faktor pertama merupakan pemberian $\mathrm{ZnO}$ terdiri dari tiga level, yaitu $3 \%, 6 \%$, dan $9 \%$, dan faktor kedua merupakan pemberian gliserol yang terdiri dari tiga level, yaitu 2 $\mathrm{ml}, 5 \mathrm{ml}$, dan $8 \mathrm{ml}$, dengan 3 (tiga) kali pengulangan. Metode RAL selanjutnya dianalisis menggunakan ANOVA (analysis of variances) pada tingkat signifikansi $\alpha=5 \%$. Apabila nilai F-hitung lebih besar dari pada F-tabel, berarti terdapat pengaruh yang signifikan antara konsentrasi $\mathrm{ZnO}$ dan gliserol terhadap sifat mekanik bioplastik. Variabel yang diamati dalam penelitian ini adalah: pengaruh konsentrasi $\mathrm{ZnO}$ dan gliserol terhadap nilai tensile strength bioplastik dan pengaruh konsentrasi $\mathrm{ZnO}$ dan gliserol terhadap \% elongasi bioplastik.

Sebelum diuji, sampel dipotong sesuai ukuran standar ASTM D638-14 Type IV dan diukur panjang awal sampel, kemudian sampel dijepit pada kedua ujungnya. Pengujian dilakukan hingga sampel putus dan dicatat besarnya gaya yang diperoleh dan panjang sampel setelah putus. Nilai tensile strength bioplastik dan \% elongasi bioplastik dapat dihitung dengan Persamaan 1 dan Persamaan 2 (Nuriyah, et al., 2018).

$\sigma=\frac{F}{A}$

Dimana:

$\sigma=$ kuat tarik (MPa)

$\mathrm{F}=$ gaya tarik masksimum $(\mathrm{N})$

$\mathrm{A}=$ luas penampang $\left(\mathrm{m}^{2}\right)$

$\varepsilon=\frac{L}{L_{0}} \times 100 \%$

Dimana:

$L=$ pertambahan panjang $(\mathrm{mm})$

$L_{0}=$ panjang awal (mm) 


\section{HASIL DAN PEMBAHASAN}

Penelitian ini menghasilkan bioplastik yang memiliki warna bening atau transparan. Hasil bioplastik tersebut diperlihatkan pada Gambar 1.

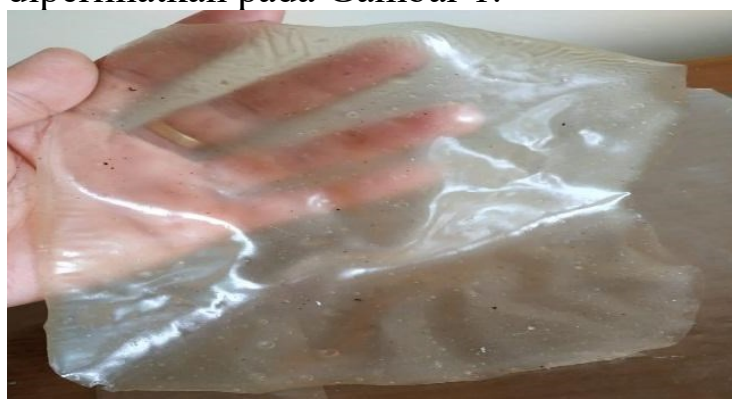

Gambar 1. Kenampakan Secara Umum Bioplastik yang Dihasilkan

Berdasarkan Gambar 1, terlihat bahwa kenampakan bioplastik yang dihasilkan tidak terlalu mulus, dimana terdapat sedikit butiran kasar berwarna coklat. Hal tersebut dikarenakan pati yang dihasilkan dari tongkol jagung kurang halus dan masih berbentuk pati yang kasar. Tekstur pati biji nangka lebih halus dan ukuran partikel yang dihasilkan lebih kecil jika dibandingkan dengan pati tongkol jagung. Oleh karena itu, pada saat pemanasan dan pengadukan, pati tongkol jagung sulit untuk terlarut sempurna. Selain itu, penambahan gliserol juga mempengaruhi kenampakan dari bioplastik yang dihasilkan. Nuryati, et al., (2019) mengatakan bahwa semakin meningkat penambahan gliserol, maka gelembung yang terbentuk pada permukaan bioplastik akan semakin besar dan rongga gelembung yang terbentuk akan semakin besar. Gliserol memiliki sifat yang mampu menyerap air (hidrofilik) sehingga kelarutannya akan semakin berkurang.

\section{Pengaruh Konsentrasi ZnO dan Gleserol Terhadap Kuat Tarik (Tensile Strength) Bioplastik}

Pengukuran nilai kuat tarik dilakukan untuk mengetahui tegangan maksimum. Dimana material, dalam hal ini adalah bioplastik, dapat menahan beban sebelum putus. Nilai tensile strength bioplastik dapat dilihat pada Gambar 2. Berdasarkan Gambar
2 dapat dilihat bahwa konsentrasi $\mathrm{ZnO}$ sangat mempengaruhi nilai tensile strength dari bioplastik Hal ini dibuktikan dengan hasil analisis ragam dimana nilai p-value konsentrasi $\mathrm{ZnO}<$ alpha 5\%. Nilai tensile strength bioplastik terbesar diperoleh pada perlakuan konsentrasi $\mathrm{ZnO} 9 \%$, yaitu sebesar 2,5788 MPa, sedangkan nilai tensile strength terkecil diperoleh pada perlakuan $\mathrm{ZnO} 3 \%$ yaitu sebesar 0,3247 MPa. Dari Gambar 2 dapat dilihat bahwa peningkatan nilai tensile strength berbanding lurus dengan penambahan konsentrasi $\mathrm{ZnO}$. Dimana semakin bertambah konsentrasi $\mathrm{ZnO}$, nilai tensile strength semakin meningkat. Saputra, et al., (2019), mengatakan bahwa penggunaan $\mathrm{ZnO}$ dalam pembuatan bioplastik dapat berperan sebagai penguat dan juga pengganti ikatan hidrogen intramolekul dan intermolekul yang hilang ketika dikombinasikan dengan campuran pati dan plasticizer gliserol. Hal ini sesuai dengan penelitian yang dilakukan oleh Amni, et al., (2015), yang dalam penelitiannya menyebutkan bahwa semakin bertambahnya penggunaan $\mathrm{ZnO}$, dapat menyebabkan nilai tensile strength semakin meningkat pula.

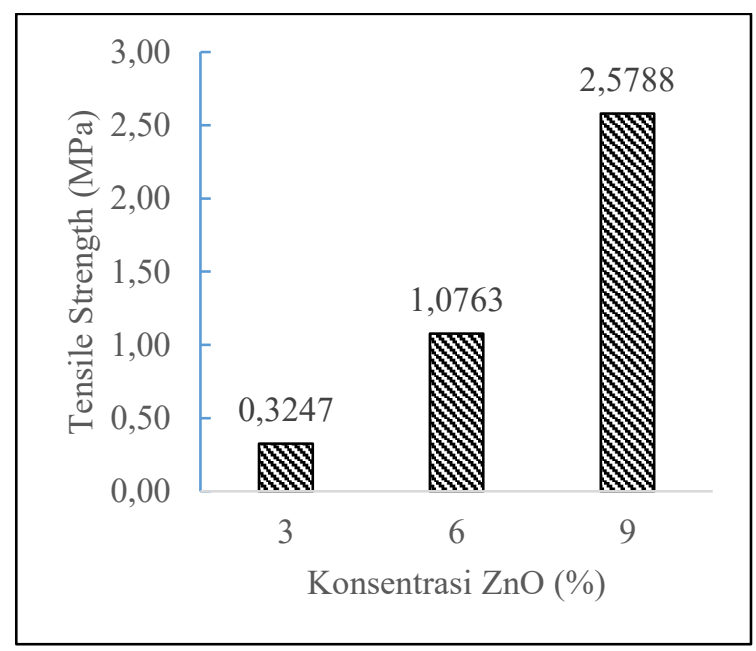

Gambar 2. Pengaruh Konsentrasi $\mathrm{ZnO}$ Terhadap Nilai Kuat Tarik (Tensile Strength) Bioplastik

Homogenitas adonan bioplastik juga mempengaruhi nilai kuat tarik bioplastik. Dalam pengadukan larutan bioplastik diharapkan larutan yang dihasilkan 
tercampur dengan rata atau homogen, sehingga larutan berada dalam kondisi yang rapat dan tidak terdapat gumpalan larutan yang terlihat pada saat telah menjadi bioplastik. Semakin rapat larutan pembuatan bioplastik, semakin besar pula energi yang dibutuhkan untuk memutuskan ikatan hidrogen yang terbentuk. Dengan kata lain bioplastik yang dihasilkan lebih kuat dan tidak mudah mengalami retak atau putus. Larutan bioplastik yang dihasilkan dengan tingkat homogenitas yang tinggi akan memberikan nilai kuat tarik pada bioplastik yang semakin tinggi pula (Coniwanti \& Alfira, 2014). Begitupun sebaliknya, jika tingkat homogenitas larutan bioplastik rendah, maka akan memberikan nilai kuat tarik bioplastik yang kecil serta akan menyebabkan bioplastik yang dihasilkan tidak mulus sehingga kenampakan bioplastik kurang bagus.

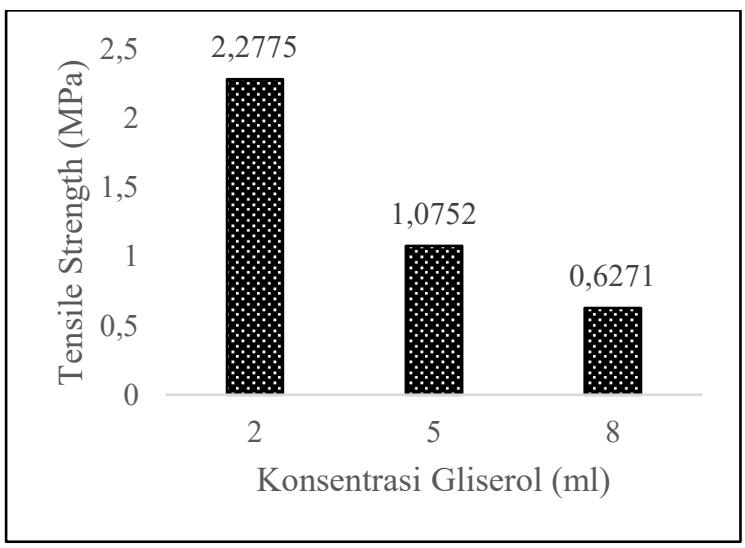

Gambar 3. Pengaruh Konsentrasi Gliserol terhadap Nilai Kuat Tarik (Tensile Strength) Bioplastik

Penggunaan gliserol dalam pembuatan bioplastik juga memengaruhi sifat kuat tarik bioplastik yang dihasilkan dengan nilai $p$-value yang diperoleh $<0,05$, dimana semakin tinggi penambahan konsentrasi gliserol dalam larutan bioplastik maka nilai kuat tarik bioplastik akan semakin rendah. Sedangkan interaksi antara konsentrasi $\mathrm{ZnO}$ dan gliserol berdasarkan hasil analisis ragam menunjukkan bahwa interaksi tidak memberikan pengaruh yang signifikan terhadap kuat tarik bioplastik (p $>5 \%$ ). Konsentrasi gliserol berbanding terbalik dengan nilai tensile strength bioplastik, dimana terlihat pada Gambar 3 bahwa nilai tensile strength tertinggi justru diperoleh pada konsentrasi gliserol $2 \mathrm{ml}$, yaitu sebesar 2,2775 MPa, sedangkan tensile strength terendah diperoleh pada penambahan gliserol $8 \mathrm{ml}$, yaitu sebesar $0,6271 \mathrm{ml}$. Hal ini sesuai dengan penelitian yang dilakukan oleh Amni, et al., (2015), dimana menyatakan bahwa semakin tinggi penambahan bahan pemlastis yang digunakan, menyebabkan semakin rendah nilai kuat tarik dari bioplastik yang dihasilkan.

Sinaga, et al., (2014), mengatakan bahwa dengan penambahan konsentrsi gliserol dalam pembuatan larutan bioplastik dapat menyebabkan penurunan kekuatan dari intermolekuler bioplastik diantara rantai polimer dan menyebabkan peningkatan fleksibilitas dari bioplastik yang dihasilkan. Semakin banyak konsentrasi gliserol yang ditambahkan dalam pembuatan larutan bioplastik menyebabkan gilserol tersebut melebihi titik jenuh dan menyebabkan molekul dari gliserol berada pada ikatan tersendiri di luar dari ikatan pati. Peristiwa inilah yang menyebabkan penurunan ikatan intramolekul antar rantai polimer dan menyebabkan rantai polimer bergerak lebih bebas (Hasanah, 2014). Namun, jika penambahan konsentrasi gliserol ke dalam larutan pembuatan bioplastik terlalu rendah, maka menyebabkan bioplastik yang dihasilkan memiliki sifat yang kurang elastis, sehingga bioplastik yang dihasilkan mudah mengalami keretakan dan menyebabkan nlai kuat tariknya akan sangat rendah.

Penambahan gliserol dalam pembuatan larutan pati dapat menurunkan sifat kaku dari pati yang merupakan bahan dasar dari pembuatan bioplastik yang memiliki sifat biodegradable. Selain itu penggunaan gilserol yang memberikan sifat lembut dan elastik dapat mempermudah pelepasan bioplastik dari cetakannya. Purbasari, et al. (2014) mengatakan bahwa penggunaan bahan plasticizer gliserol dapat 
memberikan sifat lembut dan juga fleksibel pada bioplastik.

\section{Pengaruh Konsentrasi ZnO dan Gliserol Terhadap \% Elongasi Bioplastik}

Selain dilakukan uji kuat tarik terhadap bioplastik yang dihasilkan, sifat mekanik bioplastik lainnya yang diuji meliputi \% elongasi dari bioplastik. Nilai persentase elongasi bioplastik yang dihasilkan dapat dilihat pada Gambar 4.

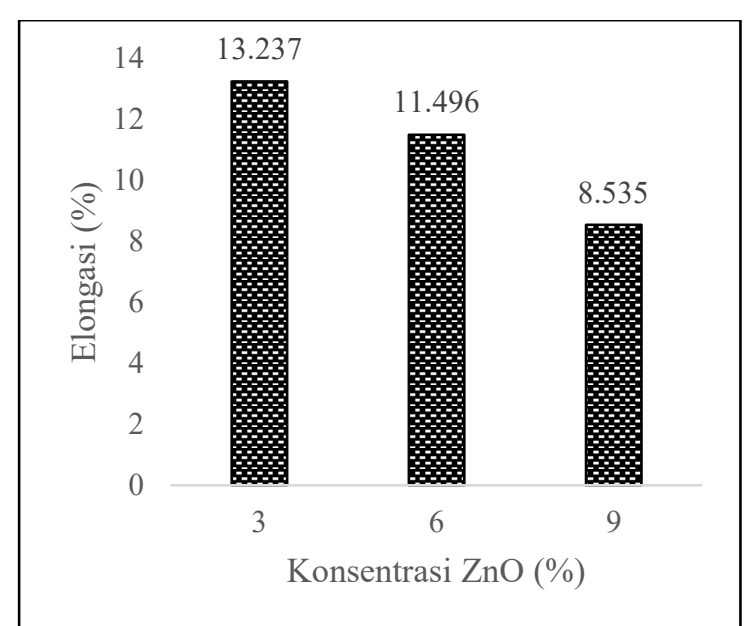

Gambar 4. Pengaruh Konsentrasi $\mathrm{ZnO}$

Terhadap \% Elongasi Bioplastik

Elongasi menunjukkan nilai regangan maksimum yang diterima oleh material (bahan bioplastik) saat mendapatkan gaya tertentu. Nilai \% elongasi diindikasikan dengan perubahan nilai panjang maksimum bioplastik sebelum mencapai kondisi putus, sehingga merupakan suatu nilai perbandingan antara nilai pertambahan panjang material bioplastik setelah diberikan beban terhadapnya dengan nilai panjang awal material bioplastik sebelum diberi beban.

Berdasarkan data yang diperoleh pada Gambar 4, dapat dilihat bahwa nilai \% elongasi bioplastik berbanding terbalik dengan penambahan konsentrasi penguat $\mathrm{ZnO}$, dimana semakin banyak konsentrasi $\mathrm{ZnO}$ yang digunakan maka nilai \% elongasi akan semakin rendah. Hasil analisis keragaman menunjukkan bahwa perlakuan penambahan konsentrasi $\mathrm{ZnO}$ berpengaruh sangat nyata $(\mathrm{p}<0,05)$ terhadap \% elongasi bioplastik. Gambar 4 menunjukkan nilai perpanjangan saat putus atau \% elongasi tertinggi diperoleh justru pada konsentrasi $\mathrm{ZnO} 3 \%$, yaitu sebesar $13,237 \%$, sedangkan $\%$ elongasi terendah diperoleh pada penambahan konsentrasi $\mathrm{ZnO} 9 \%$, yaitu sebesar $8,53527 \%$.

$\mathrm{ZnO}$ sebagai bahan penguat dalam pembuatan bioplastik akan saling berikatan dalam larutan, dimana semakin tinggi penggunaan konsentrasi $\mathrm{ZnO}$ yang digunakan dalam pembuatan bioplastic, semakin banyak dan semakin kuat pula ikatan kimianya, sehingga membuat sifat dari bioplastik menjadi semakin kaku dan menurunkan nilai \% elongasi dari bioplastik yang dihasilkan. Semakin rendahnya nilai \% elongasi yang dihasilkan seiring dengan peningkatan konsentrasi penguat $\mathrm{ZnO}$ menunjukkan hasil yang sama dengan penelitian yang telah dilakukan oleh Syahputra, et al., (2017), yang menyatakan bahwa semakin tinggi bahan pengisi yang digunakan dalam pembuatan bioplastik, ikatan antara bahan pengisi tersebut dengan bahan bioplastik akan semakin kuat, sehingga sifat dari bioplastik menjadi kaku dan menyebabkan terjadinya penurunan nilai perpanjangan saat putus dari bioplastik yang dihasilkan. Begitupula dengan penelitian yang telah dilakukan oleh Aripin, et al., (2017), dimana menunjukkan bahwa pemberian konsentrasi penguat yang semakin meningkat berbanding lurus dengan peningkatan kuat tarik dari bioplastik yang dihasilkan, tetapi berbanding terbalik dengan nilai \% elongasinya.

Konsentrasi gliserol pada Gambar 5 juga sangat mempengaruhi $\%$ elongasi bioplastik. Berdasarkan data yang diperoleh pada Gambar 5, dapat dilihat bahwa nilai \% elongasi bioplastik berbanding lurus dengan penambahan konsentrasi pemlastis gliserol, dimana semakin banyak konsentrasi gliserol yang digunakan maka nilai \% elongasi akan semakin meningkat.

Hasil analisis keragaman menunjukkan bahwa perlakuan penambahan konsentrasi gliserol berpengaruh sangat nyata $(\mathrm{p}<0,05)$ 
terhadap \% elongasi bioplastik. Gambar 5 menunjukkan nilai perpanjangan saat putus atau \% elongasi tertinggi diperoleh pada konsentrasi gliserol $8 \mathrm{ml}$, yaitu sebesar $13,8643 \%$, sedangkan \% elongasi terendah diperoleh pada penambahan konsentrasi gliserol $2 \mathrm{ml}$ yaitu sebesar 8,7447\%. Gliserol sebagai bahan yang memberikan efek yang lembut dan fleksibel pada bioplastik yang dihasilkan terletak diantara rantai polimer. Hal ini menyebabkan semakin renggangnya jarak antar rantai pati yang terbentuk, sehingga berdampak pada peningkatan nilai \% elongasi (Saputra, et al., 2019).

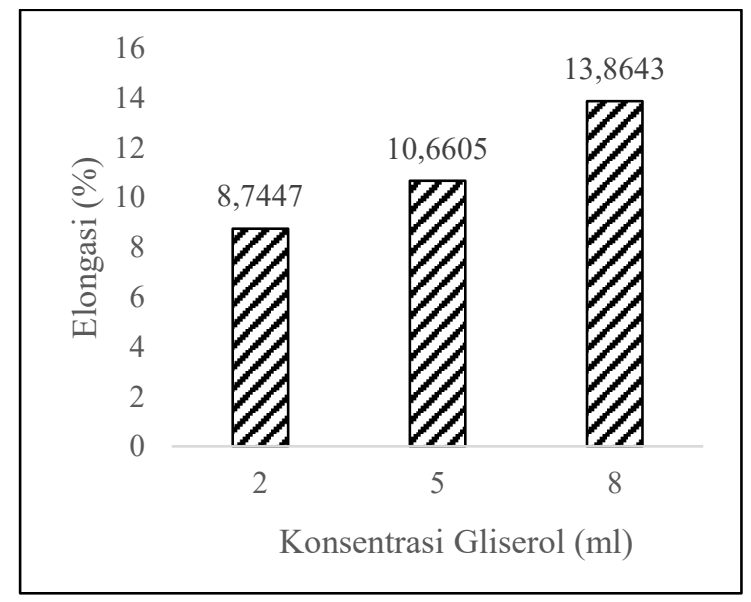

Gambar 5. Pengaruh Konsentrasi Gliserol Terhadap \% Elongasi Bioplastik

Semakin tingginya nilai \% elongasi yang dihasilkan seiring dengan peningkatan konsentrasi plasticizer gliserol yang digunakan menunjukkan hasil yang sama dengan penelitian yang telah dilakukan oleh Agustin dan Karsono (2016) yang menyatakan bahwa penambahan bahan pemlastis gliserol dalam pembuatan film bioplastik dapat membuat bioplastik menjadi semakin elastis, sehingga menyebabkan nilai elongation at break yang diperoleh semakin meningkat, tetapi mengakibatkan nilai tensile strength menurun.

\section{KESIMPULAN DAN SARAN}

\section{Kesimpulan}

Penggunaanan konsentrasi $\mathrm{ZnO}$ dan gliserol memengaruhi sifat mekanik bioplastik yang dihasilkan Dimana semakin tinggi penggunaan $\mathrm{ZnO}$, nilai kuat tarik bioplastik semakin meningkat, sedangkan nilai \% elongasi yang dihasilkan semakin rendah. Nilai \% elongasi bioplastik berbanding lurus dengan penambahan konsentrasi pemlastis gliserol. Dimana semakin banyak konsentrasi gliserol yang digunakan maka nilai \% elongasi akan semakin meningkat. Nilai tensile strength bioplastik terbesar diperoleh pada perlakuan konsentrasi $\mathrm{ZnO}$ sebesar 9\% yaitu sebesar 2,5788 MPa. Konsentrasi gliserol berbanding terbalik dengan nilai tensile strength bioplastik, dimana nilai tensile strength tertinggi diperoleh pada konsentrasi gliserol $2 \mathrm{ml}$ sebesar 2,2775 MPa. Nilai \% elongasi tertinggi diperoleh pada konsentrasi $\mathrm{ZnO} 3 \%$ sebesar 13,237\%, sedangkan dari pengaruh konsentrasi gliserol, nilai \% elongasi tertinggi diperoleh pada konsentrasi gliserol $8 \mathrm{ml}$ sebesar $13,8643 \%$.

\section{Saran}

Perlu dilakukan penelitian lebih lanjut mengenai perbandingan komposisi pati biji nangka dan tongkol jagung dalam menghasilkan bioplastik dengan sifat mekanik yang lebih baik.

\section{DAFTAR REFERENSI}

Agustin, Y.E., \& Padmawijaya, K.S. (2016). Sintesis Bioplastik dari Kitosan-Pati Kulit Pisang Kepok dengan Penambahan Zat Aditif. Jurnal Teknik Kimia, 10(2), 40-48.

Amni, C., Marwan, \& Mariana. (2015). Pembuatan bioplastik dari pati ubi kayu berpenguat nano serat jerami dan ZnO. Jurnal Litbang Industri, 5(2), 91-99. 
Aripin, S., Bungaran, S., \& Elvi, K. (2017). Studi Pembuatan Bahan Alternatif Plastik Biodegradable Dari Pati Ubi Jalar Dengan Plasticizer Gliserol dengan Metode Melt Intercalation. Jurnal Teknik Mesin (JTM), 6(2), 7984.

Asngad, A., Amella, R., \& Aeni, N. (2018). Pemanfaatan Kombinasi Kulit Kacang dengan Bonggol Pisang dan Biji Nangka untuk Pembuatan Plastik Biodegradabledengan Penambahan Gliserol. Bioeksperimen, 4(1), 11-19.

Bourtoom, T. (2008). Edible Films and Coatings: Characteristics and Properties, International Food Research Journal, 15(3), 237-248.

Coniwanti, P., Laila, L., \& Alfira, M.R. (2014). Pembuatan Film Plastik Biodegradable dari Pati Jagung dengan Penambahan Kitosan dan Pemlastis Gliserol. Jurnal Tekhnik Kimia, 20(4), 22-30.

Hasanah, N., Kemala, T., \& Sjahriza, A. (2014). Pembuatan dan pencirian plastik pati tapioka dengan pemlastis gliserol. Skripsi. Departemen Kimia Fakultas Matematika dan Ilmu Pengetahuan Alam Institut Pertanian Bogor. Bogor.

Nuriyah, L., Saroja, G., Ghufron, M., Razanata, A., \& Rosid, N.F. (2018). Karakteristik Kuat Tarik dan Elongasi Bioplastik Berbahan Pati Ubi Jalar Cilembu dengan Variasi Jenis Pemlastis. Natural B, 4(4), 177-182.

Nuryati, Jaya, J.D., \& Norhekmah. (2019). Pembuatan Plastik Biodegradable dari Pati Biji Nangka. Jurnal Teknologi Agro-Industri, 6(1), 20 - 30.

Pranamuda. (2011). Pengembangan Bahan Plastik Biodegradable Berbahan Baku Pati Tropis. http://wwwstd.ryu.titech.ac.jp/ indon esia/zoa/paper/htmL/papr.

Purbasari, A., Ekky, F.A., \& Raizka, K.M. (2014). Bioplastik Dari Tepung dan Pati Biji Nangka. Prosiding SNST ke5. Fakultas Teknik Universitas Wahid Hasyim. Semarang.

Saputra, W., Amna, H., \& Bambang, A.H. (2019). Pengaruh Konsentrasi Seng Oksida (ZnO) dan Penambahan Gliserol terhadap Karakteristik Bioplastik dari Pati Umbi Gadung (Dioscorea hispida Deenst). Jurnal Rekayasa dan Manajemen Agroindustri, 7(4), 531-540.

Sinaga, R.F., Ginting, G.M., Ginting, M.H.S., \& Hasibuan, R. (2014). Pengaruh Penambahan Gliserol Terhadap Sifat Kekuatan Tarik dan Pemajangan saat Putus Bioplastik dari Pati Umbi Talas. Jurnal Teknik Kimia USU, 3(2), 19-24.

Syahputra, A.F., Bahruddin, \& Irdoni, H. (2017). Pengaruh kadar filler $\mathrm{ZnO}$, plasticizer gliserol dan nisbah air terhadap sifat dan morfologi bioplastik berbasis pati sagu. Jurnal FTEKNIK, 4(2), 1-9.

Wardah, I., \& Hastuti, E. (2015). Pengaruh Variasi Komposisi Gliserol dengan Pati dari Bonggol Pisang, Tongkol Jagung, dan Enceng Gondok Terhadap Sifat Fisis dan Mekanis Plastik Biodegradable. Jurnal Neutrino, 7(2), 77-85. 